\title{
The Labor Market Effects of Right-to-Work Laws, 2010-2014
}

\author{
Philip G. Hoxie, Michael R. O’Herron, Matthew L. Floyd, Aidan C. McLaughlin, Paul M. Sommers \\ Department of Economics, Middlebury College, Middlebury, VT, USA \\ Email: psommers@middlebury.edu
}

How to cite this paper: Hoxie, P.G., O'Herron, M.R., Floyd, M.L., McLaughlin, A.C. and Sommers, P.M. (2017) The Labor Market Effects of Right-to-Work Laws, 20102014. Open Journal of Social Sciences, 5, 16. https://doi.org/10.4236/jss.2017.52001

Received: November 25, 2016

Accepted: January 22, 2017

Published: January 25, 2017

Copyright $\odot 2017$ by authors and Scientific Research Publishing Inc. This work is licensed under the Creative Commons Attribution International License (CC BY 4.0).

http://creativecommons.org/licenses/by/4.0/

\begin{abstract}
The authors use contiguous county pairs to study the effects of Right-to-Work (RTW) laws on employment-to-population ratios and labor force participation rates since the end of the Great Recession (2009). For counties located in the West and Midwest census regions, annual changes in employment-topopulation ratios and labor force participation rates were either equal or significantly higher in RTW states than in non-RTW states between 2010 and 2014. In the South, the recovery was discernibly faster in non-RTW states.
\end{abstract}

\section{Keywords}

Right-to-Work Laws, Great Recession, Employment-to-Population Ratios, Labor Force Participation Rates

\section{Introduction}

Since the 1947 passage of Taft-Hartley, which enabled states to pass Right-toWork (RTW) laws, there has been a large number of empirical papers attempting to estimate the effects of RTW laws on various market outcomes-unionism, employment and wage growth. The impact of RTW laws on labor market outcomes since the end of the Great Recession has, however, largely gone unstudied.

\section{Literature Review}

In the 1970s and ' 80 s, economists estimated the effects of RTW laws on flows into unionism through organizing (see, for example, Ellwood and Fine [1]), as well as other labor market outcomes such as employment and wage growth. Providing reliable estimates of RTW causal effects in explaining the differences in union membership among the states, however, has proven problematic given the difficulty of holding constant the effect of other variables on union membership (see Lumsden and Petersen [2] and Moore and Newman [3]), along with 
the very small number of RTW states following the initial passage of Taft-Hartley.

In more recent studies of RTW laws, Holmes [4], who excluded western states from his analysis, found a large increase in manufacturing activity in RTW states relative to non-RTW states. Economists have also found that the absence of RTW laws results in higher wages and union participation and lower employment (see, for examples, Abraham and Voos [5] and Stevens [6]). However, the effects of RTW laws on employment-to-population ratios (hereafter EPRs) and labor force participation rates (LFPRs) since the end of the Great Recession (June 2009) have largely gone unstudied. The EPR refers to the proportion of a county's working-age population that is employed. The LFPR refers to the percentage of the county's population that is either employed or unemployed (but actively seeking work).

\section{Method}

Here, we use contiguous bordered county pairs (hereafter county pairs) to study the post-recession labor market effects of RTW laws, in much the same way Dube, Lester, and Reich [7] used them to study the effects of minimum wage laws on earnings and employment, under the rationale that "contiguous counties are relatively similar, and hence form better controls, especially with respect to employment trends." Such an approach in the minimum wage literature has been somewhat controversial due to sensitivity to specification and time period (see, for example, Addison, Blackburn, and Cotti [8]). That said, we believe that the idea of examining the post-Great Recession impact on employment and labor force participation rates in contiguous counties across state borders with and without RTW laws is a worthy endeavor.

To determine if counties in states with RTW laws recovered faster since the Great Recession than did their counterparts in non-RTW states with respect to employment-to-population ratios (EPRs) and labor force participation rates (LFPRs), we compare EPRs and LFPRs in county pairs between 2010 and 2014. For each county pair, employment and labor force data were collected from the US Bureau of Labor Statistics (https://www.bls.gov/lau/\#ex14). Data between 2010 and 2014 on the working age population (16 years of age or over) were collected from the U.S. Census Bureau

(https://www.census.gov/popest/data/counties/totals).

The list of counties on the borders between RTW and non-RTW states was constructed by merging tables from the US Census Bureau using Google Fusion Tables (2015). If a county in an RTW state (for example, La Paz county in Arizona) bordered three counties across the border in a non-RTW state (for example, San Bernardino, Imperial, and Riverside counties in California), we recorded three different county pairs. We excluded counties in Michigan (2012), Indiana (2012), and Wisconsin (2015), because all three states enacted RTW legislation after 2010. Our sample includes 353 county pairs in fifteen RTW states (AZ, NV, KS, UT, NE, WY, OK, IA, TN, VA, ND, SD, AR, ID, and TX) and twelve non-RTW states (CA, CO, IL, KY, MD, MN, MO, MT, NM, OR, WA, and WV) involving thirty different state matchups (see Figure 1.) 


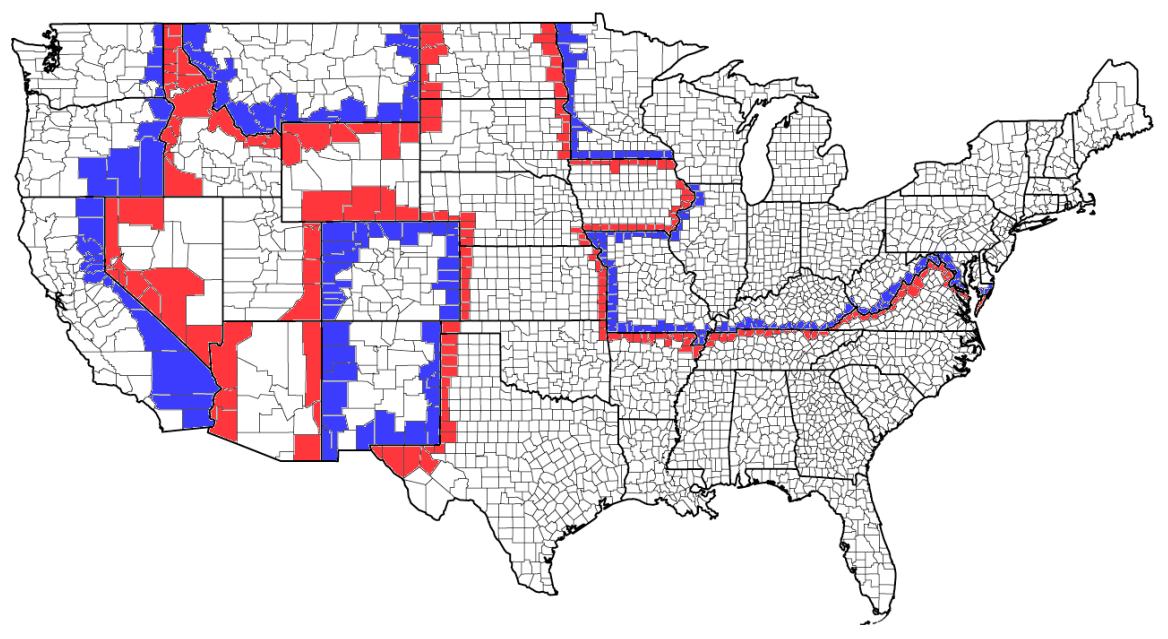

Figure 1. Counties on the borders between RTW (red) and non-RTW (blue) states.

For the states included in our sample, the percentage of workers represented by unions (see https://www.bls.gov/news.release/pdf/union2.pdf, January 28, 2016) varies considerably by census region (West, 14.5 percent; Midwest, 13.1 percent; and South, 7.4 percent). Thus based on the location of the county pair, we further divided the sample into three different census regions of the U.S.: 95 county pairs in the West, and 129 each in the Midwest and South (no Northeastern state borders an RTW state).

\section{Results and Discussion}

We ran a series of paired $t$-tests for the difference between the county's EPR and LFPR by RTW status for each year between 2010 and 2014. The results for all 353 county pairs showed that for each of the five years counties in RTW states had significantly higher average EPRs $(p<0.0001)$ and significantly higher average LFPRs $(p<0.0001)$ than did their counterparts in non-RTW states, which is consistent with most pre-recessionary findings. But, once the sample is divided into census regions, these results only hold true for those counties located in the South and Midwest. In contrast, the average EPRs and LFPRs in the RTW counties were equal to those in non-RTW counties in the West census region for each of the five years (using $\alpha=0.10$ ). Table 1 and Table 2 summarize the results of the paired $t$-tests for EPRs and LFPRs, respectively.

For the entire sample, there was no discernable difference in year-to-year changes with respect to EPRs and LFPRs between the two groups of counties ( $\alpha=$ 0.05), save for the difference between 2010 and 2011. But again, within census regions, some differences were notable. Counties in RTW states located in the West experienced larger average changes in EPR from 2010 to $2011(\mathrm{p}=0.0335)$ and again from 2011 to 2012 ( $\mathrm{p}=0.0241$ ), while counties in RTW states located in the South experienced smaller average changes (than their non-RTW state counterparts) from 2011 to 2012 ( $\mathrm{p}=0.0139)$ and again from 2012 to $2013(\mathrm{p}=$ 0.0001). In the Midwest, EPRs increased in counties in RTW states (but decreased in counties in non-RTW states) between 2012 and 2013 ( $\mathrm{p}<0.0001)$. 
Insofar as LFPRs are concerned, the regional effects in the Midwest and the South were similar to those found for EPRs, that is, counties located in RTW states in the Midwest (South) recovered faster (slower) than those in non-RTW states. Table 3 and Table 4 summarize the results of the paired $t$-tests on year-to-year changes in EPRs and LFPRs, respectively.

Table 1. Summary of paired $t$-tests on employment-to-population ratios, by year and census region.

\begin{tabular}{ccccc}
\hline & \multicolumn{3}{c}{ Census Region } \\
\hline Year & West & Midwest & South & All Three Census Regions \\
\hline 2010 & $0.1236^{*}$ & 0.0001 & $<0.0001$ & $<0.0001$ \\
2011 & 0.2575 & 0.0004 & $<0.0001$ & $<0.0001$ \\
2012 & 0.5762 & 0.0070 & $<0.0001$ & $<0.0001$ \\
2013 & 0.8649 & 0.0007 & $<0.0001$ & $<0.0001$ \\
2014 & 0.6192 & 0.0013 & $<0.0001$ & $<0.0001$ \\
\hline
\end{tabular}

*Two-tailed $p$-value on the paired difference between the average employment-to-population ratio for counties in RTW states less the average employment- to-population ratio for counties in non-RTW states.

Table 2. Summary of paired $t$-tests on labor force participation rates, by year and census region.

\begin{tabular}{ccccc}
\hline & \multicolumn{3}{c}{ Census Region } \\
\hline Year & West & Midwest & South & All Three Census Regions \\
\hline 2010 & $0.1819^{*}$ & 0.0081 & $<0.0001$ & $<0.0001$ \\
2011 & 0.2709 & 0.0070 & $<0.0001$ & $<0.0001$ \\
2012 & 0.4730 & 0.0239 & $<0.0001$ & $<0.0001$ \\
2013 & 0.7034 & 0.0029 & $<0.0001$ & $<0.0001$ \\
2014 & 0.4654 & 0.0038 & $<0.0001$ & $<0.0001$ \\
\hline
\end{tabular}

*Two-tailed $p$-value on the paired difference between the average labor force participation rate for counties in RTW states less the average labor force participation rate for counties in non-RTW states.

Table 3. Summary of paired $t$-tests on year-to-year changes in employment-to-population ratios, by census region.

\begin{tabular}{ccccc}
\hline & & \multicolumn{3}{c}{ Census Region } \\
\hline Year to Year & West & Midwest & South & All Three Census Regions \\
\hline $2010-2011$ & $0.0335^{*}$ & 0.1110 & 0.2198 & 0.0256 \\
$2011-2012$ & 0.0241 & 0.5203 & $0.9861^{\star *}$ & 0.4886 \\
$2012-2013$ & 0.1504 & $<0.0001$ & $0.9999^{\star *}$ & 0.0711 \\
$2013-2014$ & 0.9010 & 0.8063 & 0.1382 & 0.5667 \\
\hline
\end{tabular}

*One-tailed $p$-value on the paired difference between the average year-to-year change in the employment-to-population ratio for counties in RTW states less the average year-to-year change in the employment-to-population ratio for counties in non-RTW states. ${ }^{* *}$ Note that a one-tailed $p$-value greater than 0.95 implies that the average change was greater for counties in non-RTW states than for counties in RTW states. 
Table 4. Summary of paired $t$-tests on year-to-year changes in labor force participation rates, by census region.

\begin{tabular}{ccccc}
\hline & \multicolumn{3}{c}{ Census Region } \\
\hline Year to Year & West & Midwest & South & All Three Census Regions \\
\hline $2010-2011$ & $0.1491^{\star}$ & 0.0575 & 0.0163 & 0.0050 \\
$2011-2012$ & 0.0803 & 0.2453 & $0.9737^{* *}$ & 0.3387 \\
$2012-2013$ & 0.1956 & $<0.0001$ & $0.9999^{* *}$ & 0.1226 \\
$2013-2014$ & 0.9241 & 0.4626 & 0.1697 & 0.4599 \\
\hline
\end{tabular}

*One-tailed $p$-value on the paired difference between the average year-to-year change in the labor force participation rate for counties in RTW states less the average year-to-year change in the labor force participation rate for counties in non-RTW states. ${ }^{*}$ Note that a one-tailed $p$-value greater than 0.95 implies that the average change was greater for counties in non-RTW states than for counties in RTW states.

A number of shortcomings of this study should be kept in mind. In the first place, the two counties that constitute a contiguous pair may differ in geographical size, demographics, and composition of industry. For example, one county may be home to disproportionately many retired persons, while its paired county across the state border may not. One county may be closer to its respective state's largest city. The employment-to-population ratio could be misleading because the county's working age population includes only residents in that county, but the number employed in a county may include workers who do not reside in that same county or even state. Labor force participation rates can rise even as the labor force shrinks, so long as the working age population falls even faster. That is, changes ascribed to RTW laws may be due to demographic changes.

\section{Conclusion}

In summary, an analysis of 353 contiguous bordered county pairs between 2010 and 2014 (five years after the Great Recession) reveals strong differences between the effects of RTW laws on recovery rates from the Great Recession across census regions. For counties located in the West and Midwest, annual changes in employment-to-population ratios and labor force participation rates were either equal or significantly higher in RTW states than in non-RTW states. In the South, although average EPRs and LFPRs were higher in RTW states than in non-RTW states, the recovery was discernibly faster in non-RTW states.

\section{References}

[1] Ellwood, D.T. and Fine, G. (1987) The Impact of Right-to-Work Laws on Union Organizing. Journal of Political Economy, 95, 250-273. https://doi.org/10.1086/261454

[2] Lumsden, K. and Petersen, C. (1975) The Effect of Right-to-Work Laws on Unionization in the United States. Journal of Political Economy, 83, 1237-1248. https://doi.org/10.1086/260392

[3] Moore, W.J. and Newman, R.J. (1975) On the Prospects for American Trade Union Growth: A Cross-Section Analysis. The Review of Economics and Statistics, 57, 435- 
445. https://doi.org/10.2307/1935903

[4] Holmes, T.J. (1998) The Effect of State Policies on the Location of Manufacturing: Evidence from State Borders. Journal of Political Economy, 106, 667-705.

https://doi.org/10.1086/250026

[5] Abraham, S.E. and Voos, P.B. (2000) Right-to-Work Laws: New Evidence from the Stock Market. Southern Economic Journal, 67, 345-362. https://doi.org/10.2307/1061474

[6] Stevens, L.K. (2009) The Effect of Endogenous Right-to-Work Laws on Business and Economic Conditions in the United States: A Multivariate Approach. Review of Law and Economics, 5, 595-614. https://doi.org/10.2202/1555-5879.1352

[7] Dube, A., Lester, T.W. and Reich, M. (2010) Minimum Wage Effects Across State Borders: Estimates Using Contiguous Counties. The Review of Economics and Statistics, 92, 945-964. https://doi.org/10.1162/REST a 00039

[8] Addison, J.T., Blackburn, M.L. and Cotti, C.D. (2015) On the Robustness of Minimum Wage Effects: Geographically-Disparate Trends and Job Growth Equations. IZA Journal of Labor Economics,4, 1-16. https://doi.org/10.1186/s40172-015-0039-z

Submit or recommend next manuscript to SCIRP and we will provide best service for you:

Accepting pre-submission inquiries through Email, Facebook, LinkedIn, Twitter, etc. A wide selection of journals (inclusive of 9 subjects, more than 200 journals)

Providing 24-hour high-quality service

User-friendly online submission system

Fair and swift peer-review system

Efficient typesetting and proofreading procedure

Display of the result of downloads and visits, as well as the number of cited articles

Maximum dissemination of your research work

Submit your manuscript at: http://papersubmission.scirp.org/

Orcontact jss@scirp.org 